\title{
Correction to: Characterizing antibiotics in LCA-a review of current practices and proposed novel approaches for including resistance
}

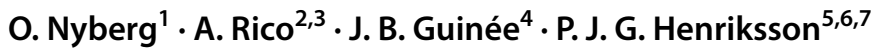

Published online: 9 August 2021

(c) The Author(s) 2021

\section{Correction to: The International Journal of Life Cycle Assessment https://doi.org/10.1007/s11367-021-01908-y}

The online version of the original article can be found at https://doi.org/10.1007/s11367-021-01908-y

The original version of this article unfortunately contained mistakes in Eqs. 1-8

and should have read:

$$
\begin{aligned}
\text { Characterization factor } & =\text { Fate factor }\left(\frac{\mathrm{kg}_{\text {in compartment }}}{\frac{\mathrm{kg}_{\text {emited }}}{\mathrm{day}}}\right) \\
& \times \text { Exposure factor }\left(\frac{\frac{\mathrm{kg}_{\text {inake }}}{\mathrm{day}}}{\mathrm{kg}_{\text {in compartment }}}\right) \\
& \times \text { Effect factor }\left(\frac{\text { disease cases }}{\mathrm{kg}_{\text {emitted }}}\right)
\end{aligned}
$$

$E F_{A B R}=\frac{0.5}{H C_{50}}$

$$
\begin{aligned}
C F_{A B R} & =\text { Fate factor }\left(\frac{\mathrm{kg}_{\text {in compartment }}}{\frac{\mathrm{kg}_{\text {emited }}}{\mathrm{day}}}\right) \\
& \times \text { Exposure factor }\left(\frac{\mathrm{kg}_{\text {bioavailable }}}{\mathrm{kg}_{\text {in compartment }}}\right) \\
& \times \text { Effect factor }\left(\frac{P A F m^{3} \text { day }}{\mathrm{kg}_{\text {emitted }}}\right)
\end{aligned}
$$

The original article can be found online at https://doi.org/10.1007/ s11367-021-01908-y.

O. Nyberg

oskar.nyberg@su.se

1 Department of Ecology, Environment and Plant Sciences, Stockholm University, Svante Arrhenius väg 20A, Stockholm, Sweden

2 IMDEA Water Institute, Science and Technology Campus of the University of Alcalá, Avenida Punto Com 2, 28805 Alcalá de Henares, Madrid, Spain

3 Cavanilles Institute of Biodiversity and Evolutionary Biology, University of Valencia, c/ Catedrático José Beltrán 2, Paterna, 46980 Valencia, Spain $\partial_{x, p, \text { sector,reg }}=\sqrt{\ln ^{O R_{x, p, s e c t o r, r e g}}}$

$A B F_{x, p, r e g}=A B U_{x, \text { hum }, \text { reg }} \times \partial_{x, p, \text { hum }, \text { reg }}+A B U_{x, \text { vet }, \text { reg }} \times \partial_{x, p, v e t, r e g}$

$\frac{D A L Y}{k g A B_{\text {xemitted }}}=\frac{D A L Y_{x, p_{1}, \text { reg }}}{A B F_{x, p_{1}, \text { reg }}}+\frac{D A L Y_{x, p_{2}, \text { reg }}}{A B F_{x, p_{2}, \text { reg }}}+\cdots+\frac{D A L Y_{x, p_{n}, r e g}}{A B F_{x, p_{n}, \text { reg }}}$

$\frac{D A L Y}{k g A B_{\text {xemitted }}}=\frac{D A L Y_{x, p, \text { reg }}}{A B U_{x, \text { hum }, \text { reg }} \times \sqrt{\ln ^{\text {OR x,phlum,reg }}}+A B U_{x, \text { vet,reg }} \times \sqrt{\ln ^{\text {OR } x, \text { vel,reg }}}}$

$\frac{0.87 D A L Y}{k g 3 G C_{\text {emitted }}}=\frac{191883 D A L Y}{2.7 \cdot 10^{5} \mathrm{~kg} \times 0,81406+1.39 \cdot 10^{4} \mathrm{~kg} \times 0}$

Open Access This article is licensed under a Creative Commons Attribution 4.0 International License, which permits use, sharing, adaptation, distribution and reproduction in any medium or format, as long as you give appropriate credit to the original author(s) and the source, provide a link to the Creative Commons licence, and indicate if changes were made. The images or other third party material in this article are included in the article's Creative Commons licence, unless indicated otherwise in a credit line to the material. If material is not included in

4 Institute of Environmental Sciences (CML), Leiden University, Einsteinweg 2, Leiden 2333 CC, The Netherlands

5 Stockholm Resilience Centre, Stockholm University, Kräftriket 2B, 10691, Stockholm, Sweden

6 Beijer Institute of Ecological Economics, Royal Swedish Academy of Sciences, Box 50005, 10405 Stockholm, Sweden

7 WorldFish, Jalan Batu Maung, 11960 Bayan Lepas, Penang, Malaysia 
the article's Creative Commons licence and your intended use is not permitted by statutory regulation or exceeds the permitted use, you will need to obtain permission directly from the copyright holder. To view a copy of this licence, visit http://creativecommons.org/licenses/by/4.0/.
Publisher's Note Springer Nature remains neutral with regard to jurisdictional claims in published maps and institutional affiliations. 